\title{
Immunoglobin G Phospholipid Unit per Milliliter
}

National Cancer Institute

\section{Source}

National Cancer Institute. Immunoglobin G Phospholipid Unit per Milliliter. NCI Thesaurus. Code C117971.

A unit for semiquantitative measurement of IgG autoantibodies to proteins associated with negatively charged phospholipids evaluated in ELISA serum anticardiolipin or anionic phospholipid assay against an established reference standard, per unit of volume equal to one milliliter. 